\title{
Maternal Communicative Behavior as a Factor in the Development of Communication in Children with Down Syndrome
}

\author{
Yulia A. Razenkova, Galina Yu. Odinokova, Ekaterina B. Ayvazyan* \\ Institute of Special Education, Russian Academy of Education, Moscow, Russia \\ *Corresponding author. E-mail: ajwaza@yandex.ru
}

Background. Special features of communicative development in children with Down Syndrome are reported to correlate with intellectual disability, while their mothers' communication with them is considered to be a reaction to difficulties in building rapport with the child. The cultural-historical approach to human psychological and mental development (Vygotsky, 1982) supports research into the contribution of maternal behavior to the development of communication in children with Down Syndrome.

Objective. To analyze the relationship between the development of responsive and initiative communicative actions in children with Down Syndrome and features of maternal communicative behavior.

Design. The subjects were 15 pairs of mothers and their children diagnosed with "trisomy 21, Down Syndrome, full (or complete) type of trisomy" and 18 pairs of mothers and their typically developing children. The children in the experimental group are from 18 to 36 months old, the age of mothers is from 24 to 41 years. The children in the control group are from 18 to 36 months old; the mothers' age is from 20 to 44 years. The research included collection of video data and expert video recording analysis. Communication was recorded of mothers and their children without a toy, and then with a toy. Videos were made three times, every 1.5 or 2 weeks, and each session lasted 20 minutes; two videos were analyzed, excluding the first one. The analysis was performed by three experts - researchers at the Federal State Budget Scientific Institution "Institute of Special Education of the Russian Academy of Education" - calculating the frequency of the children's responsive and initiative communicative actions. A qualitative analysis of the mothers' communicative behavior was conducted: Repeated patterns of the mothers' communicative behavior in both groups were identified, and the number of mothers with these communicative actions was calculated.

Results. Mothers' actions that correlated with the development of responsive and initiative communicative actions in typically developing children were identified, including: The adult caregiver addresses her child directly and personally; she pays attention to the child's actions and supports them; she plays with the child as with an equal. The 
communicative behavior of mothers of children with Down Syndrome did not differ from that of the mothers of typically developing children in terms of the behavioral characteristics listed above. The development of responsive and initiative communicative actions in children with Down Syndrome correlates with a greater number of characteristics of maternal communicative behavior, such as: continuing the communication despite approximate, uncertain, or contradictory signals from the child; creating vivid and positive emotional support for interactions; and keeping in mind the child's language and motor limitations.

Conclusion. Our research suggests that for the development of communication in children with Down Syndrome, maternal communicative actions that correlate with the development of communication in typically developing children are not sufficient.

Keywords: development of communication in children, communicative behavior of children, communicative behavior of the mother in communication with a child, children with Down Syndrome.

\section{Introduction}

The genetic disorder Down Syndrome (DS) can cause significant obstacles to the development of communication, which is an essential condition for the mental health of a child.

According to various authors, the development of communication in children with DS at an early age has a number of distinct features in terms of the sensitivity and initiative behavior of the child, features which are traditionally used as criteria for quality assessment of communication (Mukhamedrakhimov, 2003; Smirnova, Galiguzova, Yermolova, \& Meshcheryakova, 2003;). In the body of literature on interaction of mother and child with DS (Fidler, 2005; Mukhamedrakhimov, 2003; Odinokova, 2016b; Palmov, 2006; Panarina, 2004; Spiker, Boyce, \& Boyce, 2002 , etc.), many works show that children with DS have a delay in responsive behavior - eye contact, smiling, and vocalizations. The frequency of the child's nonverbal behavioral responses during interaction is significantly lower, the response latency period is longer, and the responses are reported to be less intensive and affectively colorless due to the affective state of the child (Hughes, 2012; Panarina, 2004). The children with DS are not expressive; their smiles are described as muted and their vocalizations are considered atypical (Fidler, 2005). Initiatives in children with DS are marked by low frequency (the number of pointing hand gestures is reported to be low), low intensity, and lack of persistence (Ayvazyan \& Odinokova, 2016; Cebula, Moore, \& Wishart, 2010; Odinokova, 2015; Palmov \& Mukhamedrakhimov, 2008, etc.).

Maternal communicative behavior can have its unique characteristics too. On the one hand, mothers of children with DS are described as less engaged in interaction: They are mostly in a low mood, lacking in enthusiastic, emotional and expressive speech; they don't repeat their child's sounds and expressions - they don't "mirror them" (Panarina, 2004). On the other hand, compared with mothers of typically developing children, the communicative behavior in the mother of a child with DS is described as hyperactive, directive, and more obtrusive; she speaks more strictly to the child, more persistently, giving more orders (Field, 1990; Mukhamedrakhimov, 2003, etc.). 
Yet there is also research that describes mothers' behavior in interaction with their children with DS as more effective than that of mothers of typically developing children: It is reported to be better structured and more predictable for the child, focused on development and learning, more sensitive to the child's signals (Palmov \& Mukhamedrakhimov, 2008).

Considerable individual differences in parents' behavior during interaction are also noted, with no single behavioral portrait emerging of the mother of a child with DS (Ayvazyan \& Odinokova, 2012; Inevatkina, 2009).

Features of communicative behavior in children with DS are believed to stand in direct correlation with intellectual disability - with delayed information collecting and attention disorder (Carr, 1991; Kumin, 2004; Moore, Oates, Hobson, \& Goodwin, 2002), while particular features of the mother's behavior are considered to be reactions to difficulty in building rapport and attempts to make up for it (Cunningham \& Glenn, 1991; Moore, Oates, Hobson, \& Goodwin, 2002; Mukhamedrakhimov, 2003). Specific responsive behavior in children could be interpreted by the mother as reluctance to reply on the part of the child. Due to the specific nature of the actions and the low predictability of the child's behavior, the adult caregiver may get confused and fail to understand the child's signals. As a result, mothers often don't understand their children, don't respond to their initiatives, don't pause to let the child come up with a response (Panarina, 2004; Spiker at al, 2002; Vaughn et al., 1994). Excessive maternal activity is interpreted by some authors as an attempt to compensate for the child's low activity in interaction and to ease or prevent behavioral problems (Cicchetti \& Beeghly, 1993; Mukhamedrakhimov, 2003).

With the cultural-historical approach to human psychological development, the focus shifts from biological to social factors that influence the development of communication in children with a genetic disorder (Vygotsky, 1982) and raises the question of the mother's behavior and its contribution to the development of responsive and initiative communicative actions in the child (Razenkova, 2017). Such an approach can have many applications, as it is potentially an excellent step toward preventing and overcoming difficulties in the development of communication in children with DS, by implementing a goal-oriented strategy for changing mothers' communicative behavior.

The aim of the present research is to investigate maternal communication as a factor of (condition for) the development of communicative action in children with DS.

According to the cultural-historical approach, human communication is acquired (not innate) (Lisina, 2009). This process starts from the very first days of life and develops through the child's interaction with the mother or other adult caregivers. The key factor here is the caregiver's values-based attitude toward the child: how the adult feels and thinks about the child. Initially, the adult caregiver meets the baby's natural needs and the need for new experiences, as the adult is a vivid and informative object for the child to explore. It is essential that the adult caregiver be "loving and caring" when interacting with the child, treating the child as an equal partner in communication, who has his/her own intentions and wishes. The child needs such attention, and the communicative need (in its first meaning as social reciprocity) arises as a need for getting caring attention from an adult caregiver. Driven by this need, an child first only responds to initiatives of the adult and 
then begins to actively ask for attention, inviting the adult into communication. Thus begins the development of initiative actions (Lisina, 2009).

Certain of the mother's communicative actions - such as giving her loving and benevolent attention to her child - are therefore required for the development of the child's need to communicate, which will be expressed in the child's behavior through responsive and initiative actions. Assuming that the development of communication in children with DS works the same way, we can formulate a hypothesis: The maternal communicative behavior required for the development of responsive and initiative communicative actions in children with DS has its own special characteristics, which are different from those of mothers of typically developing children.

The objectives of the research were:

- to conduct a comparative assessment of the representativity of responsive and initiative actions in communicative behavior in children with DS and in typically developing children;

- to determine mothers' communicative actions that are significant for the development of responsive and initiative communicative actions in children at an early age;

- to analyze mothers' communicative behavior that correlates with the development of responsive and initiative communicative actions in children with DS.

\section{Method}

\section{Study Subjects}

The subjects were 15 pairs of mothers and their children diagnosed with "trisomy 21, Down Syndrome, full (or complete) type of trisomy"; the children are from 18 to 36 months old $(27.7 \pm 5.8)$. The age of the mothers in the experimental group was from 24 to 41 years $(33.3 \pm 5.3)$. The control group comprised 18 pairs; the children were from 18 to 36 months old $(25.7 \pm 5.4)$; the mothers' age was from 20 to 44 years $(27.7 \pm 6.8)$. In both groups, the following covariates were balanced: family size (more than one child, $46.7 \%$ of families in the experimental group and $44.4 \%$ of families in the control group, $\varphi^{*}=0.28$, non-significant differences; an extended family, which includes grandparents, made up $46.7 \%$ of the experimental group and $27.8 \%$ of the control group, $\varphi^{*}=1.127$, non-significant differences); household income (low income $-13.3 \%$ of families in the experimental group and $16.7 \%$ of families in the control group, $\varphi^{*}=0.267$; average income $-60 \%$ and $66.7 \%$ respectively, $\varphi^{*}=0.396$, non-significant differences; high income $-26.7 \%$ and $16.7 \%$, respectively, $\varphi^{*}=0.699$, non-significant differences). The groups had differences in the educational level of the mothers (high education $-60 \%$ of the mothers in the experimental group, $27.8 \%$ of the mothers in the control group, $\varphi^{*}=1.89 ; \mathrm{p} \leq 0.05$ ), but an additional analysis did not prove this variable to correlate with the mothers' communicative behavior (Ayvazyan, Odinokova, \& Razenkova, 2017). All the families with children with DS were provided with early intervention services (in-home services of special education teachers aimed at monitoring of somatic growth and care counseling; classes on how to teach object manipulation, play, self-help, speech). 


\section{Research Methods}

The research included collection of video data and expert analysis of the videorecorded communications of mothers and their young children.

Video materials collection procedure. The videotaping was conducted no earlier that at the third or fourth time that the investigator met with the family, allowing the investigator and the subject-pair to first build rapport and some level of trust. The first two times, the investigator spoke to the mother with her child present and conducted psychological testing of the mother and assessment of the child's neuropsychological development. In the control group, the videotaping was performed at home, whereas in the experimental group it was done at a place very familiar to the child, for instance at home or in a playroom at the early intervention center where the families attended classes. First, the mothers were asked to communicate with their children without a toy, according to the protocol: "Interact with your child the way you usually do". Then a standard set of toys was offered, including a matryoshka nesting-doll, a Seguin Form Board, a pyramid, some blocks, a toy car, a ball, a small doll, a cup, a spoon, a hairbrush, a handkerchief or fabric napkin, and four pictures. The next protocol suggested: "Choose any toy, then interact and play with your child the way you usually do". The interaction of the mother-child pair was videoed three times, every 1.5 or 2 weeks, and each session took 20 minutes; two video recordings were analyzed, excluding the first one.

Video materials analysis. In the process of analysis, stories were identified in the mother-child interaction. By stories we mean episodes, complete to a certain extent, that have a clearly outlined beginning, a continuation, and an end of the interaction. The beginning is marked by one of the partners initiating an interaction (performing an initiative communicative action). In the continuation period, the partners can either support each others' initiative actions or not. These stories were converted into text - dialogues that consist of sequences of verbal utterances and "behavioral messages" (movements, vocalizations, evocative expressions of an emotional reaction by mimicry, the expression of the eyes, body posture, gestures, etc.) of the mother and her child.

Then, the frequency of the children's responsive and initiative communicative actions was calculated. The indicators of initiative behavior at the age of two are "various appeals to the adult caregiver: The child is demonstrating skills, asking for help, involved in joint actions, seeking an evaluation of his/her actions and emotional feedback for his/her own experiences" (Smirnova, Galiguzova, Yermolova, \& Meshcheryakova, 2003, p. 58). "Sensitivity is revealed in the child's responsive actions when they are performed in response to the adult's addressing him/her (the child takes the offered object, accepts help, tries to "mirror" or imitate the adult's actions, reacts to praise and reproach)" (ibid, p. 36). For the statistical analysis, we used the data about the number of children in whose behavior repeated response and initiative communications actions could be observed ( 3 or more times in 20 minutes of recording).

A qualitative analysis of mothers' communicative behavior was performed, which required the classification of elements of behavior, due to the high individual variability of phenomena observed. To meet this objective, we used the methodological approach presented in the work "The use of video surveillance for identification of the internal processes of pre-verbal development in infants" (Be- 
lova, Nosulenko, \& Ushakova, 2016). Upon reviewing the footage, both in regularspeed and freeze-frame mode, we developed a "cross-classification analysis grid" (contingency table). This is a list of classifications with informative descriptions of mothers' communicative actions (Ayvazyan, Kudrina, Odinokova, Orlova, \& Razenkova, 2018). Repeated patterns of mothers' communicative behavior in both groups were defined in general terms in the grid. The classifications are followed by remarks and examples, which give reason to conclude that the expert evaluation of the video data was given without subjectivity. Then in the cross-classification analysis grid, each of the mothers' behavioral messages was classified in terms of its communicative actions. Communicative behavior in mothers was classified by three experts, researchers at the Federal State Budget Scientific Institution "Institute of Special Education of the Russian Academy of Education", Moscow, Russia. When controversies arose in the analysis of episodes, they were classified according to the experts' collaborative decision, if necessary making corrections to the transcription and adding these to the grid (following the open coding principle of the grid) (Belova, Nosulenko, \& Ushakova, 2016).

The number of mothers displaying the specific communicative actions was calculated in order to perform the statistical analysis. The multifunctional Fisher's angular transformation $\varphi^{*}$-index and Fisher's exact test were used for comparison of the communicative characteristics of the groups "mother-child with DS" and "mother-typically developing child".

\section{Results}

Comparison of the frequency of responsive and initiative communicative actions in children with DS with that in typically developing children exhibited a significant difference in responsive communicative actions: $40 \%$ of the children with DS and $5.6 \%$ of the children in the control group showed a low frequency of responsive communicative actions to the mother's signals $\left(\varphi^{*}=2.556 ; \mathrm{p} \leq 0.01\right)$. Thus, when video recorded, significantly more children with DS ignored their mother's initiatives in interactions or refused to respond to them, avoided tasks, did not imitate the mother's activities, excluded the mother from their play, etc.

With respect to initiative communicative actions, a different picture emerges. The number of children with a low number of initiative actions showed no statistically significant difference between the two groups: 7 children with DS and 5 typically developing children performed actions that attracted the adult's attention no more than twice in 20 minutes of video recording ( $46.7 \%$ and $27.8 \%$, respectively, $\varphi^{*}=1.127$, which is a nonsignificant difference). In interactions, those children were passive, waiting for the partner to take the initiative and preferring to explore toys and other objects on their own.

It is only at the extremes that differences are observed: Two children with DS did not exhibit any initiative actions throughout all the video recordings, whereas no such cases were observed in the control group. Three children in the control group initiated communication with their mothers more than 10 times in 20 minutes of recording, while no child with DS did. So, with respect to initiative actions, it is noteworthy that both in the group of children with DS and in the control group there is a large range of individual differences. 
The qualitative study of communicative behavior of the mothers highlighted a number of repeated communicative actions in their interaction with their children. These communicative actions are outlined, with remarks and examples, in the cross classification analysis grid (contingency table) that was subsequently used for classification and quantitative assessment of mothers' behavior.

Afterwards, a comparison was made of the communicative development of the children (that is, their responsive and initiative communicative actions) with the communicative behavior of their mothers. This entailed examining the relationship between the communicative characteristics in the children and certain communicative actions (or lack thereof) in the mothers in both groups (see Table 1).

Table 1

Fisher's exact test values $\varphi$ computed to examine the relationship between communicative actions of children and their mothers in both groups $^{1}$

\begin{tabular}{|c|c|c|c|c|}
\hline \multirow[b]{2}{*}{$\begin{array}{l}\text { Communicative actions } \\
\text { of mothers }\end{array}$} & \multicolumn{2}{|c|}{$\begin{array}{l}\text { Responsive communicative } \\
\text { actions }\end{array}$} & \multicolumn{2}{|c|}{$\begin{array}{l}\text { Initiative communicative } \\
\text { actions }\end{array}$} \\
\hline & $\begin{array}{l}\text { in children } \\
\text { with DS }\end{array}$ & $\begin{array}{l}\text { in children } \\
\text { of the control } \\
\text { group }\end{array}$ & $\begin{array}{l}\text { in children } \\
\text { with DS }\end{array}$ & $\begin{array}{l}\text { in children } \\
\text { of the control } \\
\text { group }\end{array}$ \\
\hline $\begin{array}{l}\text { Uses first/second person } \\
\text { when addressing her child }\end{array}$ & $0.87^{\star \star}$ & $0.69^{\star *}$ & $0.76^{\star \star}$ & $0.57^{\star}$ \\
\hline $\begin{array}{l}\text { Comments on events in the } \\
\text { surroundings }\end{array}$ & $0.58^{\star}$ & $0.54^{*}$ & $0.47^{1}$ & $0.72^{\star *}$ \\
\hline $\begin{array}{l}\text { Supports all the child's } \\
\text { initiatives }\end{array}$ & $0.87^{\star *}$ & 0.45 & $0.76^{\star *}$ & $0.56^{*}$ \\
\hline $\begin{array}{l}\text { Plays along with her child } \\
\text { as an equal }\end{array}$ & $0.74^{* *}$ & 0.22 & $0.64^{\star *}$ & $0.55^{\star}$ \\
\hline $\begin{array}{l}\text { Comes up with innovative } \\
\text { elements when playing and } \\
\text { during interactions }\end{array}$ & 0.49 & 0.22 & $0.61^{*}$ & $0.55^{\star}$ \\
\hline $\begin{array}{l}\text { Responds to her child's } \\
\text { actions as to an initiative }\end{array}$ & $1.00^{* *}$ & 0.24 & $0.87^{\star \star}$ & $0.62^{\star *}$ \\
\hline $\begin{array}{l}\text { Accepts any response by } \\
\text { her child without criticism }\end{array}$ & $0.58^{*}$ & -0.08 & $0.76^{* *}$ & 0.18 \\
\hline $\begin{array}{l}\text { Openly expresses positive } \\
\text { emotions }\end{array}$ & $0.76^{\star *}$ & 0.39 & $0.61^{*}$ & 0.17 \\
\hline Praises her child & $0.58^{\star}$ & 0.27 & $0.76^{\star *}$ & -0.06 \\
\hline $\begin{array}{l}\text { Gives a negative evaluation } \\
\text { of her child }\end{array}$ & $-0.87^{\star \star}$ & -0.39 & $-1.00^{\star *}$ & -0.45 \\
\hline $\begin{array}{l}\text { Points out the child's failure } \\
\text { to understand }\end{array}$ & $-0.72^{\star *}$ & - & $-0.87^{\star *}$ & - \\
\hline $\begin{array}{l}\text { Presents questions and } \\
\text { tasks without keeping in } \\
\text { mind her child's abilities }\end{array}$ & -0.27 & - & $-0.53^{\star}$ & - \\
\hline
\end{tabular}

1 The $\varphi$ value doesn't reach an extreme point in this case, so it is just the trend that is observed here. However, there is a significant negative correlation between the two covariates (behavioral characteristics) "Comments on events in the surroundings" and "Child doesn't take any initiative actions” $(\varphi=-0.55, \mathrm{p} \leq 0.05)$. 
As can be seen, only two characteristics of mothers' communicative behavior have statistically significant positive correlation both with repeated responsive actions and repeated initiative actions of children from both the experimental and the control group. Those characteristics (covariates) are as follows: "using first/ second person when addressing her child" (66.6\% of mothers of children with DS; $88.9 \%$ of the control group mothers) and "commenting on events in the surroundings" ( $66.6 \%$ of mothers of children with DS; $83.3 \%$ of the control group mothers). The first of these characteristics means that everything the mother says is addressed to her child and that when addressing her child she does not use the third person grammatical form. The second characteristic means that if, during play and other interaction, a child is distracted by some phenomenon or object, the mother calls her child by name or refers to the toddler in her comments showing a neutral or positive attitude, after which she gets the child back to their current activity.

With respect to the children's performing (or not performing) repeated initiative actions, in both groups this was related to further characteristics of the mother's behavior (Table 1). The mother responds to almost every initiative her child takes, and her response is coherent with the situational context ("supports all the child's initiatives"; $66.6 \%$ of mothers of children with DS; $77.7 \%$ of the control group mothers). The mother performs playing actions and uses objects as a means to communicate the way her child does - as opposed to observing and guiding the play through instructions and recommendations ("plays along with her child as an equal"; $73.3 \%$ of mothers of children with DS; $44.4 \%$ of the control group mothers). When a child encounters difficulty playing or loses interest in a game, the mother simplifies it or changes the point of the game; she invents a new character, suggests solutions not defined by the terms of the game at the beginning ("comes up with innovative elements when playing and during interactions"; $46.6 \%$ of mothers of children with DS; $44,4 \%$ of the control group mothers). As a response to the toddler's reactions, independent object manipulations, and vocalizing unrelated to the situational context, the mother begins to communicate or play with her child ("responds to her child's actions as to an initative"; $60 \%$ of mothers of children with DS; $50 \%$ of the control group mothers).

Comparison of the experimental and control groups revealed a considerably larger amount of statistically significant correlations in pairs of mothers and children with DS. Repeated responsive actions can be observed in those children with DS whose mothers "support all the child's initiatives" and "play along with her child as an equal". Moreover, the mothers approve any response by the child, even one that barely matches the expected answer ("accepts any response by her child without criticism"; $66.7 \%$ of mothers of children with DS; $88.9 \%$ of the control group mothers). In case of a wrong answer, they respond with a positive attitude, as they would to a joke or to the toddler's having fun. Then they let their children try again, help them get to the right answer, or finally give away the right answer.

When communicating with their children, mothers are mostly smiling, laughing, with joyful tones of voice. They observe their children's actions with interest ("openly express positive emotions"; $46.7 \%$ of mothers of children with DS; 
$72.2 \%$ of the control group mothers). In response to their actions, the children get loving touches, kisses, praise, and affectionate treatment from the mothers ("praises her child"; $67.7 \%$ of mothers of children with DS; $55.6 \%$ of the control group mothers).

There is also a significant negative correlation with a mother's "negative evaluation of her child" (46.7\% of mothers of children with DS; $27.8 \%$ of the control group mothers). In such cases, she gives a general negative evaluation of her child, mimics him/her in a teasing way, or reproaches the child through questions.

Even more of the mother's actions correlate with the development of initiative actions in children with DS. First, these include the mother's communicative actions mentioned above, which are related to the development of initiative actions in normally developing children (the mother "supports all the child's initiatives", "plays along with her child as an equal", "comes up with innovative elements when playing and during interactions", "responds to her child's actions as to an initative"). Second, these actions include the mother's communicative actions that correlate with the development of sensitivity in children with DS (the mother "accepts any response by her child without criticism", "openly expresses positive emotions", "praises her child"; the mother does not "give a negative evaluation of her child"). There proved to be two more significant negative correlations - those with such characteristics as "the mother points out the child's failure to understand" (40\% of mothers of children with DS) and "the mother presents questions and tasks without keeping in mind her child's abilities" (20\% of mothers of children with DS). The first of the above-mentioned characteristics means that the mother shows confusion and asks questions like, "What do you want? I don't get it!" Then she stops communicating altogether. Sometimes this goes along with the mother's judging such signals as the child's reluctance to continue communicating, and so she comments on it. The second characteristic is that when commenting and performing initiative and responsive actions, the mother doesn't keep in mind her child's actual speaking ability and experience with objects and manipulative actions. The mother communicates with the child as if the child were either older or younger.

As the next step of analysis, we performed a quantitative comparison, comparing the number of mothers who exhibited the communicative actions listed above in the experimental and in control groups. The study showed no statistically significant differences between the groups in terms of the number of mothers who exhibited all the communicative actions listed above, with one exception - "the mother plays along with her child as an equal". Contrary to expectations, the mothers of children with DS exhibited a playing-as-an-equal pattern more frequently ("the mother plays along with her child as an equal", $73.3 \%$ of mothers of children with DS and $44.4 \%$ of mothers in the control group, $\varphi^{*}=0.707 ; \mathrm{p} \leq 0.05$ ). Perhaps that difference might be due to playful interaction strategies that the mothers of children with DS were taught at an early intervention center. Such behavioral characteristics as "the mother points out the child's failure to understand" and "the mother presents questions and tasks without keeping in mind her child's abilities" occur due to the nontypical development of the children (with DS) and were not found in the control group. 


\section{Discussion}

Comparison of the frequency of responsive and initiative communicative actions in children with DS and in typically developing children yielded confusing results. On the one hand, the results are in line with data reported in previous literature on responsive communicative behavior disorder in children with DS (Fidler, 2005; Mukhamedrakhimov, 2003; Panarina, 2004; Seligman \& Darling, 1997; Spiker, 2002 , etc.) On the other hand, the wide range of initiative-frequency indicators in children of both groups lends support to the conjecture that it is not only biological factors, but also social ones, that affect the development of communication in children.

Establishing the relationship between mothers' communicative actions and the performance or nonperformance of repeated responsive and initiative communicative actions in children, shown by statistical analysis, yields new insights into the genesis of M. Lisina's concept of communication, which suggests that the role of the adult caregiver is pivotal in the development of communication in children; this also helps to single out the special maternal actions that provide the conditions for the development of responsive and initiative behavior in children.

"Using first/second person when addressing a child" and "commenting on events in the surroundings" - these are two of the behavioral characteristics of mothers that correlate with the development of responsive communicative actions in children in both groups, and which at first may seem of no great importance.

Example 1. "Using first/second person when addressing a child". A mother and her child ( 22 months) are sitting on the floor across from each other. The mother offers a toy box to the toddler. The box contains a toy car, small balls, blocks, and a doll. The mother looks at the toys and touches them, saying: "This is what we like". The toddler looks at the box and at the mother, then reaches out for the box. The mother says: "What do you like most? You can choose and pick up any of them!" The toddler takes a ball, cuddles it, and touches another one. Mother: "Seems you like balls the most!"

Example 2. "Commenting on events in the surroundings". A toddler (18 months) and a mother are playing patty-cake. The toddler turns away from the mother, looks at the investigator and starts vocalizing. Mother: "Right, it is a woman sitting there". The toddler looks at the mother. They continue to play.

The crucial role of these two characteristics (Examples 1 and 2) becomes obvious when compared to the opposite behavioral characteristics in mothers. In some cases, a mother commented on what was happening with her child, referring to the child in the third person (with the pronouns "he" or "she"), but mostly addressing the investigator who performed the video recording (for instance, a little girl was throwing the toys around, and her mother said: "Now she won't do anything. No, she's done now". In that case the child seems not to be an equal communication partner for the mother, who treats her like an object to take care of and control (rather than an independent subject) while the communication is with the investigator. Based on observations, this behavioral characteristic is not caused by video recording alone, as it proved to be typical of these mothers to address their statements to no one or to some kind of "imaginary observer", even when away from the video recording: "Alyona is showing in every way: Mom, go away!", "Sasha doesn't want anything at all?" 
Some mothers took a child's interest in objects or events not involved in their play or other interaction as a distraction, and reproached the child for it or just stopped communicating altogether. In such cases, the mother seemed to control the interaction, refusing to continue communication if things didn't go her way. The child's interest in the external world is either not supported or is disapproved.

We can observe that such characteristics in the mothers' behavior as "using first/second person when addressing a child" and "commenting on events in the surroundings" are signs that they are treating the child as a partner in communication, as an equal partner, whose wishes and interests are as important as the mother's own initiatives. Therefore, for the development of responsive behavior, it is essential that the adult caregiver see the child as a human being and that child be considered an active partner in communication, which can be implemented in mother's behavior through directly addressing the child (in the second person) and being involved in the child's interests.

Much more is needed for the development of initiative behavior. What is primary here is the sensitively responsive behavior of the mother when she sees the different activities of the child ("supports all her child's initiatives") and who reacts not only to the child's communicative actions, but also to non-communicative actions ("responds to her child's actions as to an initative"), continuing the dialogue in response to whatever signal her child gives. These actions of the mother "tell" the child that each and every activity of her/his is important and was noticed.

Example 3. "Supports all her child's initiatives". A toddler (18 months) is sitting on the floor and fingering the toys, exploring them. The toddler takes a cup and a spoon and looks at her mother. The toddler smacks her lips. The mother sits down facing the toddler and asks: "Is your baby doll going to drink tea?" The toddler nods and vocalizes. The vocalizing resembles the sound "yes-yes". Mother: "Let's give the baby doll some tea". Then they continue to play.

Example 4. "Responds to her child's actions as to an initative". The toddler (18 months) is sitting in his mother's arms. He turns away from his mother, looks at the camera, and vocalizes: "Ooh-ooh". The mother says: "Ooh-ooh. That is how little babies cry. You went to see little Vasya yesterday, didn't you? And he was crying. How was little Vasya crying?" Toddler: "Ooh-ooh".

Second, a particular playing behavior is needed. The mother has to be involved in playing the way her child does ("plays along with her child as an equal") and be interested in the child's vivid emotions when playing ("comes up with innovative elements when playing and during interactions").

Example 5. "Plays along with her child as an equal". A mother and her daughter (35 months) are sitting on the floor. The mother takes out a toy monkey and says to the toddler, addressing her by name: "Who is this here? A monkey?" The toddler looks at the toy monkey. Mother: "Yes, the monkey has come here to say 'hi' to you!" The toddler smiles and looks at the toy. The mother puts out the monkey's paw to the toddler saying: "Hello, hello, (child's name)!" The toddler shakes the toy monkey's hand. The mother takes a cup and pretends to give a drink to the toy. The toddler grabs the cup out of the mother's hand and "gives a drink" to the toy by herself.

Example 6. "Comes up with innovative elements when playing and during interactions". A mother and her child (24 months) are building a block-tower. The 
tower falls down. The mother puts the blocks in a line saying: "Now we've got a choo-choo train". The toddler watches, pushes the train made of blocks with his finger and shows a "train" with hand gestures, imagining he is turning the steering wheel, and imitating the sounds of a train: "Choo-choo".

In our study, there were no significant differences between the mothers in the experimental and the control group, regarding the communicative actions described above. Despite some reports in the literature that behavioral patterns in mothers of children with intellectual disability (Field, 1990; Mukhamedrakhimov, 2003; Panarina, 2004; Spiker, 2002, etc.) are unfavorable for the development of communication, the mothers of children with DS in our study did everything that was necessary for the development of responsive and initiative communicative actions in typically developing children.

However, those behavioral characteristics appeared to be insufficient for the development of communication in children with DS. In addition to the mother's being attentive to and caring about various of her child's activities ("supports all the child's initiatives") it is essential that she be willing to support any participation of her child in "the dialogue" and to accept any response from the child, even one barely matching the expected answer ("accepts any response by her child without criticism").

Example 7. "Accepts any response by her child without criticism". A mother and a toddler (18 months) are sitting on the floor. The mother shows him two matryoshka nesting-dolls of different sizes and asks: "Which one is bigger?" The toddler raises his hands (a gesture showing "big"). Mother: "That's right! It's so big!" She shows the big nesting-doll and then the small one, saying: "Here is the big one and here is the small one!" The toddler watches. The mother shows the toys again and asks: "Which nesting-doll is the big one?"The toddler reaches out for the big nesting-doll. Mother: "Good job! This is the big nesting-doll".

In addition to full engagement in play ("plays along with her child as an equal"), it is crucial that the mother provide vivid and positive emotional support, so not only does she make no critical comments about her child, but she also shares the child's fun, joy, surprise, and pleasure, which also means she enjoys the child's activities and enjoys him just the way he is "openly expresses positive emotions", "praises her child"; lack of such communication action as "gives a negative evaluation of her child").

Example 8. “Openly expresses positive emotions". A toddler (22 months), with a hairbrush and a doll in her hands, is brushing the doll's and her mother's hair. Mother: "Can you brush your hair?" The toddler lets the hairbrush drop and starts "brushing" her own hair with the doll. The mother laughs cheerfully. The toddler looks at the mother's reaction and smiles.

Example 9. "Praises her child". A mother and a toddler (22 months) are playing with a doll. The toddler puts a beanie on the doll. Mother: "Did you just put your beanie on it!? Just look at you, you did it for the first time and all by yourself! Good job, sweetie!" She strokes and kisses her child. The toddler smiles.

Example 10. "Gives a negative evaluation of her child". A toddler (22 months) is sitting at the table. Behind him, his mother has crouched down to his eye level. The toddler has a cell phone in his hands and a doll sitting on the table in front of him. Mother: "Let the doll speak on the phone!" The toddler moves the phone over 
to the doll's face. Mother: "To the mouth first... Now its too close! What you are really doing now is letting her take a bite. Say it: 'I'm always doing things this way. I can't help it."' The toddler lowers the phone, then takes it up to his ear and starts "talking" and babbling, turning away from his mother.

Communicative actions that are normally not necessary for typically developing children appear to be necessary in the DS group. Most children who have entered their second year and all children who have entered their third year have achieved a language milestone: verbal communication. Children with DS at that age use nonverbal means of communication; they may be lacking in verbal communication or their verbal communication may not be enough, just a few words of autonomous speech. Moreover, the nonverbal messages may be vague and inexpressive, which makes it hard for the mother to "read" them. (Bray, 2016; Odinokova, 2016a; Panarina, 2004). The development of communication therefore depends on the way the mother interprets the child's actions and on how she acts according to her interpretation. For instance, when the mother "points out the child's failure to understand", there is very likely to be a communication breakdown (Odinokova, 2016, 2018).

Example 11. "Points out the child's failure to understand". A toddler (33 months) and her mother are sitting on the couch. The girl has made a pyramid. The mother takes the pyramid and shows it to the child, asking: "Do you want to make it again?" The toddler looks at her mother, looks at the toy, smiles, touches the toy, moves her hand down straightaway and pushes her legs against her mother's legs. The mother addresses her by name and says again: "Do you want to play with the pyramid?" The toddler looks at her mother, smiles, then laughs and slightly pushes her mother with her legs, extends her hands against the couch, and leans back, looking down. Mother: "I don't get it, do you want to play (with the pyramid) or not?"

For the development of initiative behavior in children with DS, it is a prerequisite for the mother to know how to keep communication going if her child's nonverbal message is hard to understand.

The negative correlation between repeated initiative actions in the children with DS and a behavioral characteristic such as "the mother presents questions and tasks without keeping in mind her child's abilities" highlights that it is necessary to take into account not only the child's interests, but his/her abilities too, to be aware of them and to realize the child's limitations in speech comprehension and production, and in manipulation of objects.

Example 12. "Presents questions and tasks without keeping in mind her child's abilities". A toddler (23 months) and a mother are sitting across from each other. The toddler is producing vocalizations, babbling, and not saying any words, does not make sounds that denote concepts. The toddler is fingering some toys: a doll, a toy phone, blocks, etc. Then the child grabs the doll and starts exploring it by looking at it and tasting it. The mother asks: "What is this? What is it? Where are her eyes, can you show me?" (pause). Not looking at the mother, the toddler throws the doll, grabs the toy phone, and starts exploring it. The mother asks: "And what is that?" (pause). The toddler throws away the toy phone.

In summary, the development of initiative communicative behavior in children with DS correlates with such maternal behavior as treating the child as an equal communication partner, supporting any responses the child makes, special 
play behavior, a positive tone and praising the child, lack of criticism, attempts to understand confusing signals from the child, and keeping in mind the child's current skill levels during communication.

\section{Conclusion}

The results have led us to conclude that:

1. in communication with their mothers, children with DS show lower frequency of responsive communicative actions than typically developing children;

2. low frequency of initiative communicative actions is observed equally in the children with DS and in the typically developing children;

3. for the development of communication in a typically developing child, it is essential that the mother use the first/second person grammatical forms when addressing her child, comment on events in the surroundings, support all the child's initiatives, respond when her child takes an initiative, play along with her child as an equal, and come up with innovative elements when playing and during other interactions;

4. communicative actions necessary for the development of communication in typically developing children are found in the communicative behavior of the mothers of typically developing children just as frequently as in the communicative behavior of mothers of the children with DS;

5. in addition to the mother's communicative actions necessary for development of responsive and initiative communicative actions in typically developing children, for the development of these actions in children with DS it is essential that the mother accept any response her child makes without criticism, express positive emotions, praise the child, not give a negative evaluation of her child, present questions and tasks while keeping in mind her child's abilities, respond to confusing signals from the child by continuing to communicate (not pointing out the child's failure to understand her).

Since a prerequisite for the development of communication in children with DS is the mother's having special communicative skills, development of these skills should be taught by special education teachers. Our study can provide evidence and serve as a basis for such a training program in terms of: goal-setting, suggesting a course of action, assessment of special communicative skills developed in mothers of children with DS. This concept was experimentally tested and found empirical validation (Odinokova, 2015).

\section{Acknowledgements}

The research was performed within the project of the Ministry of Education and Science of the Russian Federation under the Federal State Budget Scientific Institution "Institute of Special Education of the Russian Academy of Education" (No. 25.9040.2017/8.9, "Scientific and methodological support for early psychological and pedagogical prevention of disability in children with health limitations"). 
The authors would like to thank Yulia Melnik for translating the article into English.

\section{References}

Ayvazyan, E. B., \& Odinokova, G. Yu. (2012). Fenomen "nepreryvayushchiysya dialog" i yego rol' v razvitii rebenka rannego vozrasta s sindromom Dauna [The phenomenon of "ongoing dialogue" and its role in the development of a child with Down syndrome]. Sindrom Dauna. XXI vek [Down syndrome. The XXI century], 1 (8), 13-17.

Ayvazyan, E. B., \& Odinokova, G. Yu. (2016). Osobennosti povedeniya rebenka rannego vozrasta s sindromom Dauna vo vzaimodeystvii s mater'yu: fenomen otkazov ot obshcheniya [Children with Down Syndrome and mother-child interaction: Behavioral features and the phenomenon of refusal to communicate]. Defektologiya [Defectology], 6, 65-70.

Ayvazyan, E. B., Odinokova, G. Yu., \& Razenkova, Yu. A. (2017). Osobennosti obshcheniya rebenka rannego vozrasta s sindrommom Dauna i yego materi v zavisimosti ot nekotorykh sotsial'no-demograficheskikh i psikhologicheskikh faktorov [Features of communication between mother and child with Down syndrome contingent upon certain sociodemographic and psychological factors]. Defektologiya [Defectology], 5, 29-35.

Ayvazyan, E. B., Kudrina, T. P., Odinokova, G. Yu., Orlova, E. V., \& Razenkova, Yu. A. (2018). Issledovaniye obshcheniya vzroslogo i rebenka pervykh let zhizni s ogranichennymi vozmozhnostyami zdorov'ya: metodicheskiy instrumentariy [Infants with health limitations: A study of adult-infant communication in the early years, with a methodological toolbox]. Al'manakh institut korrektsionnoy pedagogiki "Rannyaya pomoshch': ot issledovaniy k praktike" [Institute of Special Education edition "Early intervention: from theory to practice"], 32. Retrieved from http://alldef.ru/ru/articles/almanac-32/

Belova, S. S., Nosulenko V. N., \& Ushakova T. N. (2016) Ispol'zovaniye videonablyudeniya dlya vyyavleniya skrytykh protsessov predrechevogo razvitiya mladentsa [The use of video surveillance for identification of the internal processes of pre-verbal development in infants]. Eksperimental'naya psikhologiya [Experimental Psychology (Russia)], 9(2), 66-81. https:// doi.org/10.17759/exppsy.2016090206

Bray, M. (2016). Exploring fluency in Down Syndrome. A discussion of speech dysfluencies for professionals and parents. Albury, UK: J\&R Press Ltd.

Carr, J. (1991). Razvitiye intellekta [Development of intellect] In D. Lein \& B. Stratford (Eds.), Sovremennyye podkhody $k$ bolezni Dauna [Current approaches to Down Syndrome] (pp. 117-132). Moscow: Pedagogy.

Cebula, K. R., Moore, D. G., \& Wishart J. G. (2010). Social cognition in children with Down`s syndrome: Challenges to research and theory building. Journal of Intellectual Disability Research, 54(2), 113-134. https://doi.org/10.1111/j.1365-2788.2009.01215.x

Cicchetti, D., \& Beeghly, M. (1993). An organizational approach to the study of Down syndrome: Contributions to an integrative theory of development. In D. Cicchetti \& M. Beeghly (Eds.), Children with Down syndrome: A developmental perspective (pp. 29-62). New York: Cambridge University Press.

Cunningham, C. C., \& Glenn, S. M. (1991). Pomoshch' roditelyam. Ranneye vmeshatel'stvo v razvitiye [Aid to parents. Early intervention]. In D. Lane \& B. Stratford (Eds.), Sovremennyye podkhody k bolezni Dauna [Current approaches to Down's Syndrome] (pp. 251-263). Moscow: Pedagogy.

Fidler, D. J. (2005). The emerging Down syndrome behavioral phenotype in early childhood: Implications for practice. Infants \& Young Children, 18(2), 86-103. https://doi. org/10.1097/00001163-200504000-00003 
Field, T. M. (1990). Infancy. Cambridge, Mass.: Harvard University Press.

Hughes, D., (2012). Uchimsya obshchat'sya s rozhdeniya [Learning to communicate from birth]. Sindrom Dauna. XXI vek [Down syndrome. The XXI century], 2(9), 22-27.

Inevatkina, S.E. (2009). Vnutrennyaya pozitsiya materi rebenka rannego vozrasta s sindromom Dauna [The mindset of mothers of infants with Down syndrome] ( $\mathrm{PhD}$ thesis). Institute of Special Education, Moscow, Russia.

Kumin, L. (2004). Formirovaniye navykov obshcheniya u detey s sindromom Dauna: Rukovodstvo dlya roditeley [Parents' guidebook to developing communicative skills in children with Down Syndrome]. Moscow: Blagotvoritel'nyy fond "Downside Up".

Lisina, M. I. (2009). Problemy ontogeneza obshcheniya [Problems of the ontogeny of communication]. In M. I. Lisina, Formirovaniye lichnosti rebenka $v$ obshchenii. [Formation of the child's personality in communication] (pp. 21-129). St. Petersburg: Piter.

Moore, D. G., Oates, J. M., Hobson, R. P., \& Goodwin, J. (2002). Cognitive and social factors in the development of infants with Down syndrome. Down Syndrome. Research and Practice, 8(2), 43-52. https://doi.org/10.3104/reviews. 129

Mukhamedrakhimov, R. Zh. (2003). Mat'i mladenets: psikhologicheskoye vzaimodeystviye [Mother and infant: Psychological interaction]. St. Petersburg: Izdatelstvo Sankt-Peterburgskogo gosudarstvennogo universiteta.

Odinokova, G. Yu. (2015). Vyyavleniye i preodoleniye neblagopoluchiya v razvitii obshcheniya materi i rebenka rannego vozrasta s sindromom Dauna [Detection and intervention of difficulties in the development of communication between mother and infant with Down syndrome] (PhD thesis). Institute of Special Education, Moscow, Russia.

Odinokova, G. Yu. (2016a). O protivorechiyakh v kommunikativnykh deystviyakh rebenka rannego vozrasta s sindromom Dauna [Contradictions in communicative actions of infants with Down syndrome]. Vospitaniye i obucheniye detey s narusheniyami razvitiya [Upbringing and education of children with development disorders], 1, 45-49.

Odinokova, G. Yu. (2016b). Vzaimodeystviye materey i detey mladencheskogo i rannego vozrasta s sindromomo Dauna: analiz zarubezhnykh i otechestvennykh issledovaniy [Motherchild interaction in toddlers and infants with Down Syndrome: A review of national and international studies]. Sindrom Dauna. XXI vek [Down syndrome. The XXI century], 1(16), 22-26.

Odinokova, G. Yu. (2018). Osobennosti kommunikativnogo povedeniya detey vtorogo-tret'yego goda zhizni s sindromom Dauna i trudnosti yego interpretatsii blizkim vzroslym [Communicative behavior in 2-3 year-old children with Down Syndrome: Its special features and the difficulties in its interpretation by an adult]. Almanakh institut korrektsionnoy pedagogiki "Rannyaya pomoshch': ot issledovaniy k praktike" [The Institute of Special Education edition "Early intervention: from theory to practice"], 32. Retrieved from http://alldef.ru/ru/articles/ almanac-32/

Palmov, O. I. (2006). Psikhicheskoye razvitiye detey s sindromom Dauna v protsesse rannego vmeshatel'stva [Mental development of children with Down syndrome in early intervention] (PhD thesis). St. Petersburg: St. Petersburg State University.

Palmov, O. I., \& Mukhamedrakhimov, R. Zh. (2008). Vzaimodeystviye blizkikh vzroslykh i detey $\mathrm{s}$ sindromom Dauna v sem'ye i domakh rebenka [Interaction between children with Down syndrome and their adult caregivers in the family and in orphanages]. In R. Zh. Mukhamedrakhimov (Ed.), Emotsii i otnosheniya cheloveka na rannikh etapakh razvitiya [Emotions and interpersonal relations at the early stages of human development] (pp. 140-156). St. Petersburg: Izdatelstvo Sankt-Peterburgskogo gosudarstvennogo universiteta.

Panarina, L. Yu. (2004). Psikhologicheskaya korrektsiya vzaimodeystviya mladentsev s sindromom Dauna i ikh blizkikh vzroslykh [Psychological correction of the interaction between 
infants with Down syndrome and adult caregivers]. (PhD thesis). Samara, Russia: Samara State Pedagogical University.

Razenkova, Yu. A. (2017). Preduprezhdeniye i preodoleniye trudnostey razvitiya obshcheniya $\mathrm{u}$ detey rannego vozrasta s ogranichennymi vozmozhnostyami zdorov'ya [Prevention and intervention for difficulties in the development of communication in infants with health limitations] (Doctoral dissertation). Institute of Special Education, Moscow.

Seligman, M. \& Darling, R. B. (1997). Ordinary families, special children: A systems approach to childhood disability. New York, London: The Guilford Press.

Smirnova, E. O., Galiguzova, L. N., Yermolova, T. V., \& Meshcheryakova, S. Yu. (2003). Diagnostika psikhicheskogo razvitiya detey ot rozhdeniya do 3 let [Diagnosing mental development in children with Down syndrome from birth to 3 years]. Moscow: Moscow State University of Psychology \& Education.

Spiker, D., Boyce, G. C. \& Boyce, L. K. (2002). Parent-child interactions when young children have disabilities. In: L. M. Glidden (Ed.), International Review of Research in Mental Retardation, Vol. 25 (pp. 35-70). San Diego, USA: Academic Press.

Vaughn, B. E., Goldberg, S., Atkinson, L., Marcovitch, S., MacGregor, D., \& Seifer, R. (1994). Quality of toddler-mother attachment in children with Down syndrome: Limits to interpretation of strange situation behavior. Child Development, 65, 95-108. https://doi. org/10.2307/1131368

Vygotsky, L. S. (1982). Istoriya razvitiya vysshikh psikhicheskikh funktsiy [The history of the development of higher mental functions]. In L. S. Vygotsky, Sobranie sochinenii v shesti tomakh [Collected Works in 6 Volumes], V. 6, pp. 5-328. Moscow: Pedagogika. 